\title{
Effects of the 'Prestige' oil spill on cellular biomarkers in intertidal mussels: results of the first year of studies
}

\author{
Amaia Orbea, Larraitz Garmendia, Ionan Marigómez, Miren P. Cajaraville* \\ Biologia Zelularra eta Histologia Laborategia, Zoologia eta Biologia Zelularra Saila, Zientzia eta Teknologia Fakultatea, \\ Euskal Herriko Unibertsitatea/Universidad del País Vasco, 644 PK, 48080 Bilbao, Spain
}

\begin{abstract}
In November 2002 the tanker 'Prestige' sunk in front of the Galician coast (NW Iberian Peninsula). As a result, $>60000 \mathrm{t}$ of heavy fuel oil leaked into the sea, affecting $>1000 \mathrm{~km}$ of coastline. In order to assess the effects of the oil spill on coastal ecosystems, mussels Mytilus galloprovincialis were sampled (April, July and September 2003) in 17 locations along the Galician and Bay of Biscay coasts. In this study, 3 biomarkers were assessed: lysosomal responses as changes in the lysosomal structure and in the lysosomal membrane stability, accumulation of intracellular neutral lipids and peroxisome proliferation as induction of acyl-CoA oxidase (AOX) activity. Mussel flesh condition index and gonad developmental stages were assessed as supporting parameters. Lysosomal membrane stability was reduced in mussels from all locations, indicating disturbed health, especially in mussels from all Galician locations. Similarly, lysosomal enlargement was observed in most locations, as shown by relatively low values of the surface-to-volume ratio, although the volume density of lysosomes was low due to decreased lysosomal numbers. Overall, intracellular accumulation of neutral lipids was conspicuous in digestive tubules of mussels collected in July and was increased further in September. AOX induction was detectable in mussels sampled in April, except for those collected in Galicia. In July mussels from the most impacted stations in Galicia, Caldebarcos and Camelle, showed the highest AOX values. In conclusion, the biomarkers employed detected exposure to toxic chemicals and a disturbed status of health in mussels from the northern Iberian Peninsula after the 'Prestige' oil spill and will allow assessment of the long-term effects of the spill on the coastal ecosystems.
\end{abstract}

KEY WORDS: Cellular biomarkers · Mussels · Mytilus galloprovincialis · 'Prestige' oil spill

Resale or republication not permitted without written consent of the publisher

\section{INTRODUCTION}

In November 2002, the tanker 'Prestige' sunk in front of the Galician coast (northwestern Iberian Peninsula). As a result, $>60000 \mathrm{t}$ of heavy fuel oil leaked into the sea, affecting $>1000 \mathrm{~km}$ of coastline along the Bay of Biscay. The Galician coast was very severely impacted, but other coastal areas of special ecological relevance, such as the Biosphere's Reserve of Urdaibai, were also affected to different degrees. After such an enormous environmental disaster, it was necessary to evaluate the effects of the spill on the wildlife and natural resources. Therefore, in the spring of 2003, a monitoring programme was started along the Galician and Bay of Biscay coasts based on the use of biomarkers in intertidal mussels.

Historically, marine and coastal pollution assessment has been performed based solely on the measurements of contaminants in water, sediment and biota. However, more recently, the need to assess the biological effects of pollutants in the framework of monitoring programmes has been highlighted (Cajaraville et al. 2000). The maritime area impacted by the 'Prestige' oil spill is under the influence of the OSPAR Convention, whose 'Joint Assessment and Monitoring Programme (JAMP)' utilises biomarkers for monitoring biological effects (Stagg 1998).

Biomarkers are measurements of body fluids, cells, 
or tissues at cellular, biochemical and molecular levels that indicate the presence of pollutants (exposure biomarkers) or the magnitude of the organism's response (effect biomarkers) (McCarthy \& Shugart 1990). These measurements are considered as 'early warning signals', since changes at low levels of biological organisation (e.g. molecule, cell, or tissue) can anticipate changes at higher levels (e.g. population, community, or ecosystem). The use of individual biomarkers provides partial information about the presence of different types of pollutants and their biological consequences; thus, the utilisation of a battery of measurements, including both exposure and effect biomarkers, in selected sentinel species has been strongly recommended to be included in routine monitoring programmes (Cajaraville et al. 2000).

The biomarker approach using mussels or fish as sentinel organisms has been previously employed to assess organism exposure to and biological effects of accidental oil spills. The geographically nearest example on the Galician coast was after the 'Aegean Sea' oil spill, which occurred in La Coruña Harbour in December 1992 (Solé et al. 1996, Porte et al. 2000). In the aforementioned studies, biotransformation enzymes, oxidative stress markers and DNA-adducts in mussels were tested as possible biomarkers of impact by organic pollution. Results indicated increases in digestive gland levels of total cytochrome P-450, CYP1Alike protein and lipid peroxidation in parallel with increased levels of whole-body polycyclic aromatic hydrocarbons (PAHs) in mussels sampled closer to the spill (Solé et al. 1996, Porte et al. 2000).

Similar studies were performed after the 'Sea Empress' oil spill (1996) in SW Wales, UK, using ethoxyresorufin $O$-deethylase (EROD) activity in fish (Kirby et al. 1999), CYP1A-immunopositive protein levels, microsomal benzo(a)pyrene hydroxylase activity (Peters et al. 1999), as well as lysosomal stability of blood cells (Fernley et al. 2000) in mussels and DNA-adduct levels in mussels and fish (Lyons et al. 1997, Harvey et al. 1999) as biomarkers. In these studies biomarker responses were able to discriminate between areas directly polluted by the spill and reference locations.

By far the most studied oil spill is that resulting from the 'Exxon Valdez' wreck, which occurred in the northern Prince William Sound, Alaska, USA, in March 1989. Biomarkers were able to detect exposure of fish to hydrocarbons even $10 \mathrm{yr}$ after the spill when the proper sentinel species were chosen, as demonstrated by Jewett et al. (2002) in masked greenling Hexagrammos octogrammus and crescent gunnel Pholis laeta sampled from sites originally oiled. These organisms showed elevated levels of CYP1A in the liver vascular endothelium, liver EROD activity and biliary fluorescent aromatic compounds in comparison to fish from unoiled sites. Apart from fish, other marine species, such as sea otters Enhydra lutris, harlequin ducks Histrionicus histrionicus, Barrow's goldeneyes Bucephala islandica and pigeon guillemots Cepphus columba sampled in oiled sites had elevated levels of hepatic EROD activity and, thus, cytochrome P4501A, as well as other blood parameters, such as aspartate aminotransferase and lactate dehydrogenase, in comparison with animals from unoiled areas (Trust et al. 2000, Bodkin et al. 2002, Esler et al. 2002, Golet et al. 2002). Furthermore, these studies have shown a linkage between biomarker responses and long-term effects in populations (Peterson et al. 2003).

In the first spring period after the 'Prestige' oil spill, a monitoring programme was started along the affected northern Iberian coast, and, during 2003, 3 samplings were carried out (April, July and September) in order to cover the different stages of the reproductive cycle of mussels. The results obtained in this first year are described here. The objective of the study was to evaluate the biological effects of the 'Prestige' oil spill using a battery of exposure and effect biomarkers in mussels, Mytilus galloprovincialis, collected in 17 locations from the south of the Galician coast to the east of the northern Iberian Peninsula coast. Special care was taken to sample the Galician locations that were most impacted initially, and those Basque locations where we had previous baseline biomarker data. Lysosomal responses were used as effect biomarkers, and intracellular accumulation of neutral lipids and peroxisome proliferation were selected as exposure biomarkers. In addition, flesh condition index (Lobel \& Wright 1982) and gonad developmental stages (Seed 1969) were assessed as supporting parameters.

Lysosomal responses are used worldwide as biomarkers in mussels and fish (Marigómez et al. 2004), since they are sensitive to a wide range of types of environmental stress, including pollution ( $\mathrm{Au}$ 2004). The lysosomal membrane stability test is recommended by the OSPAR Convention to monitor the biological effects of contaminants (Stagg 1998), and is usually performed according to a standardised protocol (UNEP/RAMOGE 1999). Simple evaluation of the lysosomal dimensions also gives a good indication of the general stress condition (Cajaraville et al. 2000). In the present work, lysosomal responses were measured as changes in lysosomal membrane stability and in lysosomal structure.

Neutral lipid accumulation in mussel digestive cells was used as an indication of exposure to organic xenobiotics. According to laboratory experiments, this parameter behaves as an all-or-nothing response (Marigómez \& Baybay-Villacorta 2003). Although some studies have succeeded in using cytochrome P450related biomarkers in mussels, these are not as power- 
ful as in fish, and their utilisation in biomonitoring programmes has been recommended only for fish liver. Thus, peroxisome proliferation, assessed as the induction of the activity of the $\beta$-oxidation enzyme acyl-CoA oxidase (AOX), was measured in the present study as an alternative biomarker of PAH exposure in mussels (Cajaraville et al. 2000, 2003).

\section{MATERIALS AND METHODS}

Sampling. Mussels were collected in the intertidal zone during the lowest tides of April, July and September of 2003 in 17 locations along the northern coast of the Iberian Peninsula (Fig. 1). Six locations were selected in Galicia, and 11 in the Bay of Biscay (1 in Asturias, 4 in Cantabria and 6 in the Basque Country). The oil spill first reached and affected the coast of Galicia (Caldebarcos and Camelle were among the most affected locations), but in the following months the whole northern coast of the Iberian Peninsula was affected to different degrees. In each location, 60 adult mussels of sizes ranging from 2.8 to $6.3 \mathrm{~cm}$ shell length were collected and pre-processed immediately after sampling. Thirty mussels were opened by sectioning the adductor muscle, fixed in $4 \%$ formaldehyde containing $0.1 \mathrm{M}$ phosphate buffer and maintained in the fixative until required for analysis in the laboratory. The digestive glands of 20 mussels were dissected out and immediately frozen in liquid nitrogen for biochemical analyses. The digestive glands of the remaining 10 mussels were dissected out and divided into 2

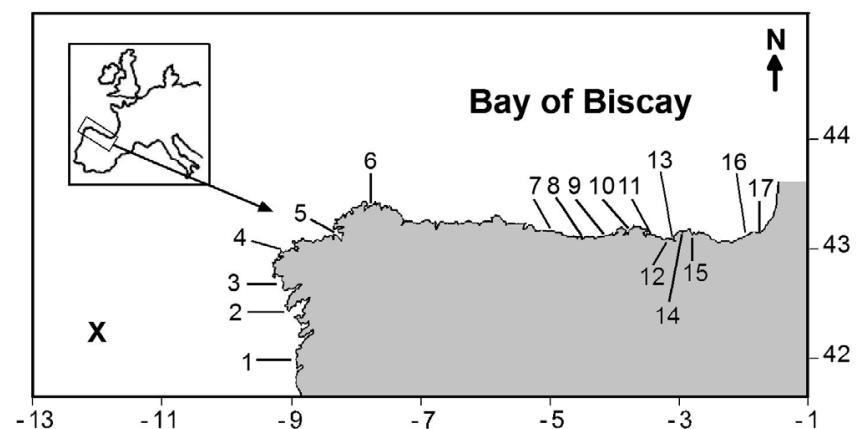

Fig. 1. Map of the coast of the northern Iberian Peninsula, showing locations where the mussels Mytilus galloprovincialis were collected. Station numbers are as follows: 1: Oia; 2: Aguiño; 3: Caldebarcos; 4: Camelle; 5: Segaño; 6: Estaca de Bares; 7: Llanes; 8: San Vicente; 9: Suances; 10: Pedreña; 11: Laredo; 12: Muskiz; 13: Arrigunaga; 14: Gorliz; 15: Mundaka; 16: Orio; 17: Hondarribia. Latitude and longitude marks are shown. Site where the 'Prestige' tanker sunk is marked by an $\mathbf{X}$. The oil spill first reached and affected the coast of Galicia (Stns 1 to 6; Caldebarcos and Camelle were among the most affected locations), but in the following months the whole northern coast of the Iberian Peninsula was affected to different degrees parts for histochemical analyses. Five middle pieces of digestive glands obtained from 5 different mussels were placed on plastic chucks aligned in a straight row. The chucks were put into cryovials and directly frozen in liquid nitrogen. The other 5 middle pieces were processed identically and stored as replicates. Frozen samples were transported to the laboratory in liquid nitrogen or in dry ice in the case of samples obtained in Galicia in order to keep them below $-80^{\circ} \mathrm{C}$, and then they were stored at $-80^{\circ} \mathrm{C}$ until required for analysis.

For several parameters the data corresponding to the sampling carried out in April are missing due to the accidental loss of the frozen samples. All parameters assessed under the light microscope were measured on slides with blind-coded labels in order to avoid subjectivity of the operator.

Reagents. Unless specified otherwise, all chemicals were reagent grade and purchased from Sigma.

Flesh condition index. Once in the laboratory, the shell and fixed flesh weights for 30 mussels from each location were measured after draining on a paper towel. Then, the flesh condition index (FCI, Lobel \& Wright 1982) was calculated as the fixed flesh weight (in $\mathrm{mg}$ ) to shell weight (in g). Usually, the mussel flesh dry weight is employed to calculate this parameter. However, due to the large number of samples collected for this study and the need to pre-process in the field, the fixed flesh weight has been used. In order to validate the usefulness of this measurement, in an additional group of mussels the wet flesh weight was obtained prior to fixation. Results indicate that there is a significant linear regression between the fixed flesh weight and the wet flesh weight $\left(R^{2}=0.9781, n=20\right.$, $\mathrm{p}<0.05)$

Gonad development. A piece of the mantle tissue of each of 10 mussels per sampling site was dehydrated in alcohol and embedded in paraffin. Histological sections $(7 \mu \mathrm{m})$ were cut with a Leitz 1512 microtome (Ernst Leitz Wetzlar) and stained with haematoxylin-eosin. Gonad developmental stages (1: resting gonad; 2 : early gametogenesis; 3 : advanced gametogenesis; 4: mature gonad; 5: spawning gonad; and 6: post-spawning gonad) were assigned after histological examination of 1 section per individual according to Seed (1969) and Cajaraville et al. (1992a).

Lysosomal membrane stability test. The lysosomal membrane stability test was performed according to a standardised protocol (UNEP/RAMOGE 1999). Serial tissue sections $(10 \mu \mathrm{m}$ thick) were cut in a Leica CM 3000 cryostat (Leica Instruments) at a cabinet temperature of $-24^{\circ} \mathrm{C}$ and at a sample temperature between -14 and $-16^{\circ} \mathrm{C}$, and stored at $-40^{\circ} \mathrm{C}$ until required for staining. Prior to staining, slides were air-dried at $4^{\circ} \mathrm{C}$ for $20 \mathrm{~min}$ and then $10 \mathrm{~min}$ at room temperature. 
Cryostat sections were introduced into $0.1 \mathrm{M}$ sodium citrate buffer ( $\mathrm{pH} 4.5)$ containing $2.5 \% \mathrm{NaCl}$ in intervals of $0,3,5,10,15,20,30$ and $40 \mathrm{~min}$ in a shaking water bath at $37^{\circ} \mathrm{C}$ to destabilise the lysosomal membrane. Afterwards, sections were incubated for $20 \mathrm{~min}$, also in a shaking water bath at $37^{\circ} \mathrm{C}$ in $0.1 \mathrm{M}$ citrate buffer ( $\mathrm{pH} 4.5$ ) containing $2.5 \% \mathrm{NaCl}, 0.04 \%$ naphthol AS-BI N-acetyl- $\beta$-D-glucosaminide dissolved in 2-methoxiethanol (Merck Bioscience) and $7 \%$ of POLIPEP as a section stabiliser. After incubation, sections were rinsed in a saline solution $(3 \% \mathrm{NaCl})$ at $37^{\circ} \mathrm{C}$ for $2 \mathrm{~min}$ in a shaking water bath. Then, sections were introduced into $0.1 \mathrm{M}$ phosphate buffer $(\mathrm{pH} 7.4$ ) containing $0.1 \%$ of diazonium dye Fast Violet B salt, at room temperature for $10 \mathrm{~min}$. Subsequently, slides were rinsed in running tap water for $5 \mathrm{~min}$, fixed for $10 \mathrm{~min}$ in $10 \%$ formaldehyde containing $2 \%$ calcium acetate at $4^{\circ} \mathrm{C}$ and rinsed in distilled water. Finally, slides were mounted in Kaiser's glycerol gelatin (Merck Bioscience) and sealed with nail varnish.

The determination of lysosomal membrane stability was based on the time of acid labilisation required to produce maximum staining. Two maximum staining peaks were observed in some cases, but only the first maximum staining peak was considered. The labilisation period was assessed under a Leitz Laborlux S (Wetzlar) light microscope using an objective lens of $40 \times$ magnification. Four measurements were made in each section. Then, a mean value was derived for each section, corresponding to an individual digestive gland.

Lysosomal structural changes. In order to quantify changes in lysosomal structure, cryostat sections $(8 \mu \mathrm{m}$ thick) from the digestive glands of 5 mussels were stained for the histochemical demonstration of $\beta$-glucuronidase activity according to Cajaraville et al. (1991). Sections were air-dried at $4^{\circ} \mathrm{C}$ for $15 \mathrm{~min}$ and then $10 \mathrm{~min}$ at room temperature. These sections were incubated in freshly prepared incubation medium consisting of $0.1 \mathrm{M}$ acetate buffer ( $\mathrm{pH} 4.5$ ) containing $2.5 \% \mathrm{NaCl}, 0.028 \%$ naphthol AS-BI- $\beta$-glucuronide dissolved in $50 \mathrm{mM}$ sodium bicarbonate and $15 \%$ polyvinyl alcohol for $20 \mathrm{~min}$ at $37^{\circ} \mathrm{C}$ in a shaking water bath. After incubation, slides were rinsed in a $2.5 \%$ $\mathrm{NaCl}$ solution for $2 \mathrm{~min}$ at $37^{\circ} \mathrm{C}$ in a shaking water bath and then transferred to a post-coupling medium containing $0.1 \mathrm{M}$ phosphate buffer ( $\mathrm{pH} 7.4$ ) with $2.5 \%$ $\mathrm{NaCl}$ and $0.1 \%$ Fast Garnet GBC for 10 min in darkness and at room temperature. Afterwards, sections were fixed for $10 \mathrm{~min}$ at $4^{\circ} \mathrm{C}$ in Baker's formol calcium containing $2.5 \% \mathrm{NaCl}$ and rinsed briefly in distilled water. Finally, sections were counterstained with $0.1 \%$ Fast Green FCF for 2 min at room temperature, rinsed several times in distilled water, mounted in Kaiser's glycerol gelatin (Merck Bioscience) and sealed with nail varnish.
The structure of lysosomes was determined by image analysis (Cajaraville et al. 1991). Slides were viewed using an objective lens of $100 \times$ magnification in a Leitz Laborlux S light microscope. Five measurements were made in each section in order to calculate the following stereological parameters: lysosomal volume density $\left(V V_{\mathrm{L}}=V_{\mathrm{L}} / V_{\mathrm{C}}\right)$, lysosomal surface density $\left(S V_{\mathrm{L}}=S_{\mathrm{L}} / V_{\mathrm{C}}\right)$, lysosomal surface to volume ratio $\left(S / V_{\mathrm{L}}=\right.$ $\left.S_{\mathrm{L}} / V_{\mathrm{L}}\right)$ and lysosomal numerical density $\left(N V_{\mathrm{L}}=N_{\mathrm{L}} / V_{\mathrm{C}}\right)$, where $V$ is volume, $S$ is surface, $N$ is number, $\mathrm{L}$ is lysosomes and $\mathrm{C}$ is digestive cell cytoplasm (Lowe et al. 1981).

Intracellular accumulation of neutral lipids. In order to quantify the intracellular accumulation of neutral lipids, cryostat sections ( $8 \mu \mathrm{m}$ thick) from the digestive glands of 5 mussels were stained using the method of Lillie \& Ashburn's Oil Red O (ORO) (Culling 1974). Sections were fixed for $15 \mathrm{~min}$ at $4^{\circ} \mathrm{C}$ in Baker's formol calcium containing $2.5 \% \mathrm{NaCl}$. Then, sections were dried at room temperature for $10 \mathrm{~min}$, washed in isopropanol $(60 \%)$ and rinsed for $20 \mathrm{~min}$ in the ORO staining solution at room temperature. This solution was freshly made by dissolving $0.5 \%$ ORO in isopropilic alcohol and afterwards diluting it 3:2 in distilled water. Stained sections were differentiated in $60 \%$ isopropanol, washed in water and counterstained with $1 \%$ Fast Green FCF for 20 min at room temperature. Finally, stained sections were mounted in Kaiser's glycerol gelatin (Merck Bioscience) and sealed with nail varnish.

Intracellular accumulation of neutral lipids was measured by image analysis in the digestive tubules of mussel digestive gland, excluding other structures such as stomach and ducts. Slides were viewed using an objective lens of $40 \times$ magnification in the Leitz Laborlux S light microscope, and 5 measurements were made in each section in order to calculate the volume density of intracellular neutral lipids $\left(V V_{\mathrm{NL}}=\right.$ $V_{\mathrm{NL}} / V_{\mathrm{C}}$ ), where $\mathrm{NL}$ are neutral lipids and other symbols as above.

Peroxisomal AOX activity. AOX activity was determined spectrophotometrically at a wavelength of $502 \mathrm{~nm}$, according to the method of Small et al. (1985), in 5 pools of 2 digestive glands per experimental group. Each pool was homogenised in $4 \mathrm{ml} \mathrm{g}^{-1}$ tissue of TVBE buffer (1 mM sodium bicarbonate, 1 mM EDTA, $0.1 \%$ ethanol and $0.01 \%$ Triton $\mathrm{X}-100$ ), $\mathrm{pH} 7.6$, using a glass-Teflon homogeniser held in an ice bath. After centrifugation at $500 \times g$ for $15 \mathrm{~min}$ at $4^{\circ} \mathrm{C}$, supernatants were diluted 1:10 in TVBE buffer and assayed for AOX activity. The assay is based on the $\mathrm{H}_{2} \mathrm{O}_{2}$ dependent oxidation of dichlorofluorescein diacetate (Molecular Probes) catalysed by an exogenous peroxidase using $30 \mu \mathrm{M}$ palmitoyl-CoA as substrate. Total protein concentration was measured using the DC pro- 
tein assay (BioRad) based on the method of Lowry et al. (1951), with $\gamma$-globulin as the standard. AOX activity is given as milliunits $\mathrm{mg}^{-1}$ of AOX protein (equivalent to $\mathrm{nmol} \mathrm{H}_{2} \mathrm{O}_{2}$ min $^{-1} \mathrm{mg}^{-1}$ protein).

Statistical analyses. The statistical analyses were made using SPSS Ver. 11.5 (SPSS). The variability of the factors sampling season and sampling location, as well as their interaction, was studied by 2 -way variance analyses (ANOVA) for each parameter, except for the labilisation period of the lysosomal membrane for which Friedman's test was applied (Sokal \& Rohlf 1995), since it is a non-parametric variable. The seasonal and geographical variability within each sampling location or season, respectively, was assessed by means of 1-way ANOVA. Differences between means were studied a posteriori by Duncan's test, except for the labilisation period of the lysosomal membrane in which the Mann-Whitney $U$-test was applied. Groups of locations whose mean values for a parameter do not differ significantly according to the Duncan or $U$-test are marked by a black circle in each row of the tables accompanying the graphs (see Figs. 3 to 7 ). The number of rows in the tables corresponds to the number of subgroups (that is, groups of locations with no statistically significant differences among them). In all cases, a $95 \%$ significance level was established. Lysosomal volume and numerical density and peroxisomal AOX activity were logarithmically transformed before statistical analyses.

\section{RESULTS}

Results obtained from the mussels Mytilus galloprovincialis sampled in 17 locations along the coast of the northern Iberian Peninsula in April, July and September 2003 are given in Figs. 2 to 7 and in Table 1. With the aim of analysing the effects of time and geographical location, 2-way ANOVAs were performed for parametric parameters (Table 2) and Friedman's test for non-parametric parameters (Table 3). The results indicated that the factors studied, including their interactions, had significant effects (at least $\mathrm{p}<$ 0.05 ) on the selected parameters.

\section{FCI and gonad development}

The mean and standard deviation values obtained for the FCI are shown in Table 1. Mussels from different locations did not show a common pattern of temporal variation. Except for 4 locations (Camelle, Suances, Laredo and Orio), higher values were found in July or September than in April. In April and July samplings, maximum and minimum values were recorded for
Table 1. Mytilus galloprovincialis. Flesh condition index in mussels sampled along the coast of the northern Iberian Peninsula in 2003. Data are $\mathrm{mg}$ fixed flesh wet weight $\mathrm{g}^{-1}$ shell weight (mean $\pm \mathrm{SD})$

\begin{tabular}{|lcll|}
\hline Location & Apr & Jul & Sep \\
\hline Oia & $457 \pm 89$ & $525 \pm 79$ & $523 \pm 73$ \\
Aguiño & $546 \pm 78$ & $585 \pm 77$ & $585 \pm 94$ \\
Caldebarcos & $622 \pm 96$ & $678 \pm 158$ & $582 \pm 80$ \\
Camelle & $634 \pm 87$ & $529 \pm 74$ & $547 \pm 69$ \\
Segaño & $518 \pm 82$ & $580 \pm 110$ & $598 \pm 95$ \\
Estaca de Bares & $622 \pm 92$ & $541 \pm 65$ & $656 \pm 101$ \\
Llanes & $507 \pm 76$ & $561 \pm 80$ & $485 \pm 77$ \\
San Vicente & $624 \pm 107$ & $641 \pm 105$ & $732 \pm 130$ \\
Suances & $625 \pm 109$ & $513 \pm 68$ & $430 \pm 64$ \\
Pedreña & $684 \pm 122$ & $722 \pm 135$ & $642 \pm 172$ \\
Laredo & $599 \pm 101$ & $553 \pm 129$ & $447 \pm 93$ \\
Muskiz & $432 \pm 69$ & $467 \pm 84$ & $425 \pm 74$ \\
Arrigunaga & $398 \pm 83$ & $538 \pm 61$ & $658 \pm 91$ \\
Gorliz & $353 \pm 66$ & $433 \pm 116$ & $442 \pm 64$ \\
Mundaka & $593 \pm 171$ & $599 \pm 95$ & $470 \pm 67$ \\
Orio & $601 \pm 118$ & $509 \pm 108$ & $556 \pm 75$ \\
Hondarribia & $732 \pm 121$ & $772 \pm 140$ & $704 \pm 153$ \\
\hline
\end{tabular}

Table 2. Mytilus galloprovincialis. Summary of the 2-way ANOVAs performed to analyse the effects of the sampling period, sampling location and the interaction between these 2 factors on the studied parameters in mussels sampled along the coast of the northern Iberian Peninsula in 2003. FCI: flesh condition index; $V v_{\mathrm{L}}$ : lysosomal volume density; $S V_{\mathrm{L}}$ : lysosomal surface density; $S / V_{\mathrm{L}}$ : lysosomal surface to volume ratio; $N V_{\mathrm{L}}$ : lysosomal numerical density; $V V_{\mathrm{NL}}$ : volume density of intracellular neutral lipids; AOX: acyl-CoA oxidase activity; df: degrees of freedom; F: Fisher's F-ratio; p: probability of $F$

\begin{tabular}{|llrcc|}
\hline Parameter & Factor & df & $F$ & $\mathrm{p}$ \\
\hline FCI & Season & 2 & 3.195 & 0.041 \\
& Location & 16 & 60.023 & $<0.001$ \\
& Season $\times$ Location & 32 & 11.385 & $<0.001$ \\
$\log V_{V_{\mathrm{L}}}$ & Season & 1 & 49.667 & $<0.001$ \\
& Location & 16 & 8.473 & $<0.001$ \\
& Season $\times$ Location & 16 & 3.291 & $<0.001$ \\
$S V_{\mathrm{L}}$ & Season & 1 & 36.486 & $<0.001$ \\
& Location & 16 & 4.445 & $<0.001$ \\
& Season $\times$ Location & 16 & 3.062 & $<0.001$ \\
$S / V_{\mathrm{L}}$ & Season & 1 & 37.314 & $<0.001$ \\
& Location & 16 & 11.368 & $<0.001$ \\
& Season $\times$ Location & 16 & 5.948 & $<0.001$ \\
$\log N V_{\mathrm{L}}$ & Season & 1 & 11.841 & 0.001 \\
& Location & 16 & 2.715 & 0.001 \\
& Season $\times$ Location & 16 & 5.49 & $<0.001$ \\
$V V_{\mathrm{NL}}$ & Season & 1 & 4.797 & 0.03 \\
& Location & 16 & 9.446 & $<0.001$ \\
& Season $\times$ Location & 16 & 5.067 & $<0.001$ \\
$\log \mathrm{AOX}$ & Season & 2 & 179.976 & $<0.001$ \\
& Location & 16 & 13.061 & $<0.001$ \\
& Season $\times$ Location & 28 & 14.885 & $<0.001$ \\
\hline \multirow{6}{*}{} & & & & \\
& & &
\end{tabular}


Table 3. Mytilus galloprovincialis. Summary of Friedman's test performed to analyse the effects of the sampling period, sampling location and the interaction between these 2 factors on the labilisation period (LP) of the lysosomal membrane in mussels sampled along the coast of the northern Iberian Peninsula in 2003. df: degrees of freedom; $\chi^{2}$ : chi square; p: probability of $\chi^{2}$

\begin{tabular}{|llrrr|}
\hline Parameter & Factor & df & $\chi^{2}$ & \multicolumn{1}{c|}{$\mathrm{p}$} \\
\hline LP & Season & 1 & 166.024 & $<0.001$ \\
& Location & 1 & 1.710 & 0.191 \\
& Season $\times$ Location & 2 & 202.987 & $<0.001$ \\
\hline
\end{tabular}

$<20 \mathrm{~min}$ ), indicative of reduced lysosomal membrane stability (Fig. 3).

In July, the lowest LP values were recorded in the Galician sampling locations, with LP values $<10 \mathrm{~min}$. According to the $U$-test, no statistically significant differences were detected among mussels from Galicia. In the Bay of Biscay, LP values were not as low. Exceptionally, in Laredo and Muskiz samples, LP values were similar to those found in Galician mussels. LP values recorded in mussels from Orio were higher (>20 min) than those from the rest of the stations. animals sampled in Hondarribia and Gorliz, respectively. In September, the lowest FCI was found in mussels from Suances and the highest value was obtained for mussels collected in San Vicente, mussels from Hondarribia showing again high values. In general, low values were recorded in Oia, Llanes, Muskiz and Gorliz in the 3 sampling periods.

Both male and female individuals were found at all sampling stations, except in Oia in September, where all individuals were male. Overall, development stage was not dissimilar between both sexes. In April, the mature gonad stage was predominant. Some mussels from Oia, Estaca de Bares and San Vicente were in advanced gametogenesis, while most individuals from Aguiño and Caldebarcos were already spawning (Fig. 2). In July, mussels from all locations were in a more advanced developmental stage than those in April, except for mussels from Llanes, which remained in the same stage. In most locations, some mussels were in the post-spawning stage, and in Camelle and Suances the beginning of a second gametogenesis cycle could be observed (Fig. 2). In September, the gonads of most mussels were in the post-spawning stage and mussels from most locations had started the second reproductive cycle (Fig. 2).

\section{Lysosomal membrane stability}

Mussels collected for this study presented, in general, low labilisation period (LP) values (mean values always
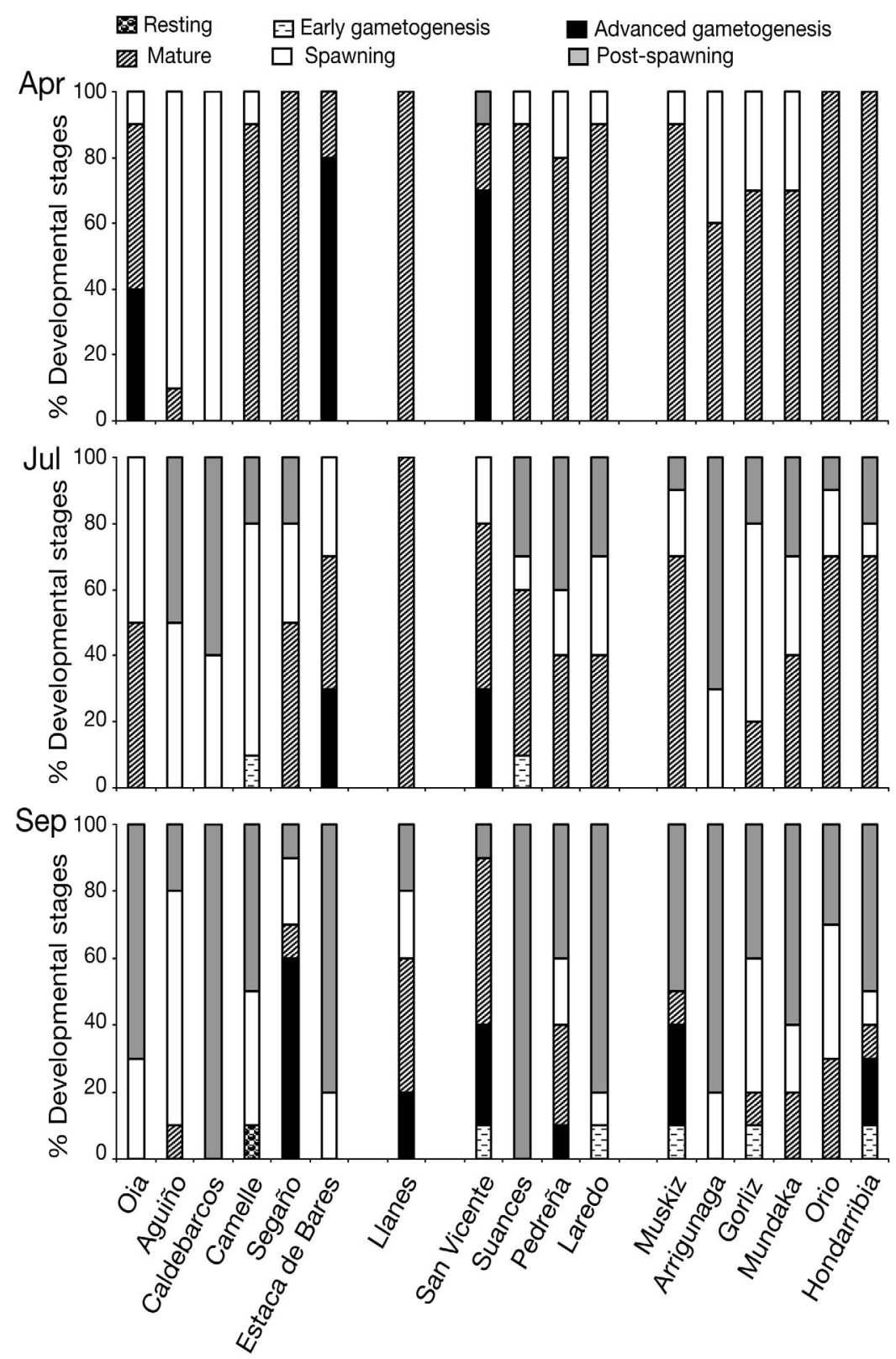

Fig. 2. Mytilus galloprovincialis. Percentage of gonad development stages in mussels sampled along the coast of the northern Iberian Peninsula in 2003 
In September, the lowest LP values were also recorded at the Galician sampling locations (LP < $10 \mathrm{~min}$ ), with the exception of Estaca de Bares (LP > 15 min; Fig. 3). In the Bay of Biscay, LP values were, in general, similar to those recorded in July, although augmented LP was recorded in mussels from Hondarribia, Pedreña and Laredo and reduced LP was found in Llanes and Arrigunaga.

\section{Lysosomal structural changes}

Only the results obtained for $V v_{\mathrm{L}}$ and $S / V_{\mathrm{L}}$ are presented, since the surface density and the numerical density showed the same trends as $V v_{\mathrm{L}}$. In general terms, $V v_{\mathrm{L}}$ and $S / V_{\mathrm{L}}$ values were low (Figs. 4 \& 5), which indicates that lysosomes in digestive cells were few but large.

In mussels collected in July, low $V v_{\mathrm{L}}$ values were recorded. The highest values of $V v_{\mathrm{L}}$ were observed in Oia, Estaca de Bares, Laredo and Hondarribia (Fig. 4). Mussels from the other sampling locations presented low $V V_{\mathrm{L}}$ values, especially those from Camelle, Llanes and Mundaka and those from Orio, the lysosomes of which were too small to be measured by image analysis (Fig. 4). The highest $S / V_{\mathrm{L}}$ values were recorded in Llanes, whereas the lowest ones were observed in Laredo and Hondarribia (Fig. 5).

In September, a general increase was observed in $V_{V_{\mathrm{L}}}$ compared to mussels sampled in July. The differences between sampling locations were less marked in September than in July, although some locations such as Llanes, Suances, Muskiz and Orio presented lower $V V_{\mathrm{L}}$ values than those found in the remainder of sampling locations (Fig. 4). Differences in $S / V_{\mathrm{L}}$ values between sampling locations were also less marked in September than in July (Fig. 5). Minimum $S / V_{\mathrm{L}}$ values were again detected in Hondarribia.

\section{Intracellular accumulation of neutral lipids}

As a general rule, the staining pattern was heterogeneous both between individuals and between groups. Overall, intracellular accumulation of neutral
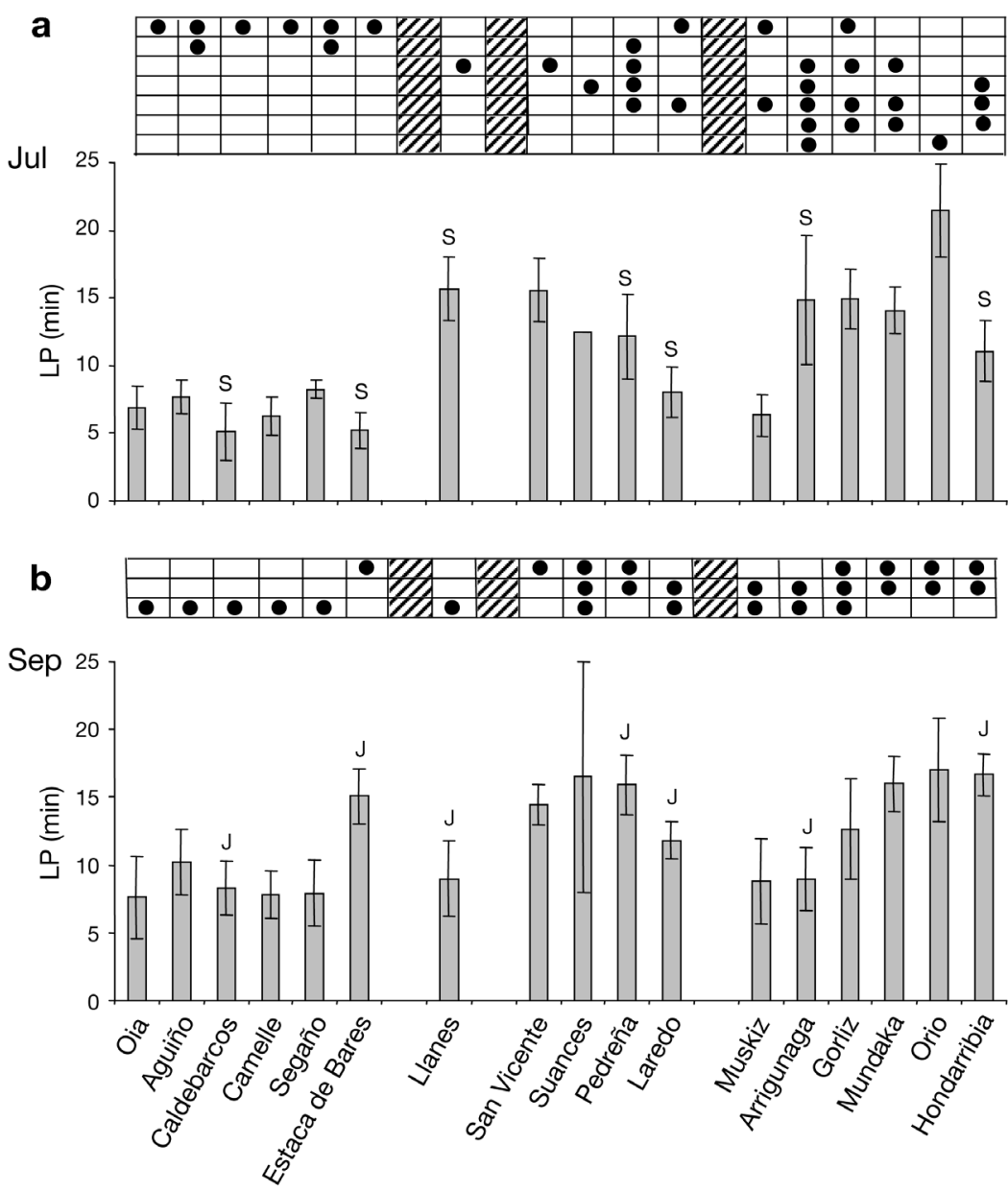

Fig. 3. Mytilus galloprovincialis. Lysosomal membrane labilisation period (LP) in digestive glands of mussels sampled along the coast of the northern Iberian Peninsula in (a) July and (b) September 2003. Error bars represent standard . Letters over bars (indicate month): statistically significant differences $(p<0.05)$ between sampling seasons for each location according to the $U$-test. Grid above each panel compares locations: black circles in same row indicate locations that are not significantly different $(p>0.05)$ for each sampling season according to the $U$-test

lipids, measured as neutral lipid volume density $\left(V V_{\mathrm{NL}}\right)$, was conspicuous in the digestive tubules of mussels collected in July and was further increased in September (Fig. 6).

In July, the highest $V_{V_{\mathrm{NL}}}$ values were recorded in Segaño, Laredo and Hondarribia. Moderate $V V_{\mathrm{NL}}$ values were found in Oia, Aguiño, Caldebarcos and Arrigunaga, and very low $V V_{\mathrm{NL}}$ values were recorded at the remainder of sampling stations (Fig. 6).

In September, the highest $V V_{\mathrm{NL}}$ values were recorded in Aguiño, San Vicente, Laredo, Arrigunaga, Gorliz and Hondarribia. Moderate $V v_{\mathrm{NL}}$ values were found in Oia, Camelle, Pedreña and Mundaka, and very low $V v_{\mathrm{NL}}$ values were recorded at the remainder of sampling stations (Fig. 6). 

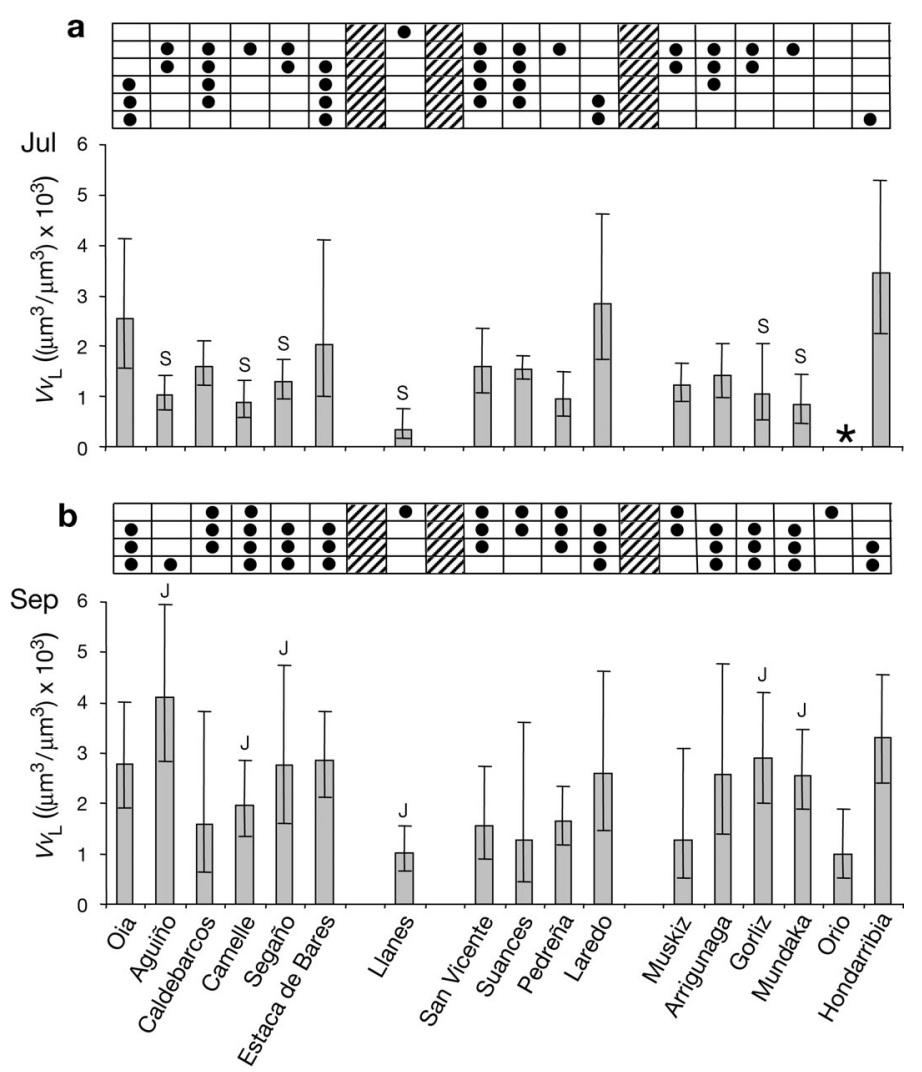

Fig. 4. Mytilus galloprovincialis. Lysosomal volume density $\left(V v_{\mathrm{L}}\right)$ in the digestive glands of mussels sampled along the coast of the northern Iberian Peninsula in (a) July and (b) September 2003. Error bars representing standard deviations are asymmetric due to the logarithmic transformation of data previous to statistical analysis. *: Lysosomes in mussels sampled in Orio in July were too small to be measured by image analysis. Letters over bars (indicate months): statistically significant differences $(p<0.05)$ between sampling seasons for each location according to 1-way ANOVA. Grid above each panel compares locations: black circles in same row indicate locations that are not statistically different $(p<0.05)$ for each sampling season according to Duncan's test after 1-way ANOVA

\section{Peroxisome proliferation}

The highest values of AOX activity were detected in mussels sampled in April, except at the Galician locations (Fig. 7). In April, individuals from the 3 Galician locations measured showed very similar values among themselves. Regarding the rest of the locations, the highest value was detected in mussels from Orio and the lowest values in Llanes and Muskiz.

In July, in general, AOX activity decreased (Fig. 7). However, the highest values were then recorded in Galicia, especially in the most impacted locations of Caldebarcos and Camelle. With respect to the other locations, the lowest value of AOX activity was detected in Hondarribia, with similar low values at Suances and Laredo.
In September, AOX activity decreased at all the Galician locations, except in Estaca de Bares, but it remained high in Camelle. At other locations, such as San Vicente, Arrigunaga and Hondarribia, AOX activities were significantly lower than in July. Mussels from Hondarribia had the lowest values of AOX activity, as in July (Fig. 7). In general, differences between sampling locations were more marked in April than in July or September.

\section{DISCUSSION}

In the first spring period after the 'Prestige' oil spill a monitoring programme was started along the coast of the northern Iberian Peninsula in order to assess the biological effects of the pollution resulting from the accident. A battery of exposure and effect biomarkers was applied to mussels collected in 17 locations from the Galician coast to the Basque coast in April, July and September 2003. The biomarkers selected were lysosomal responses, intracellular accumulation of neutral
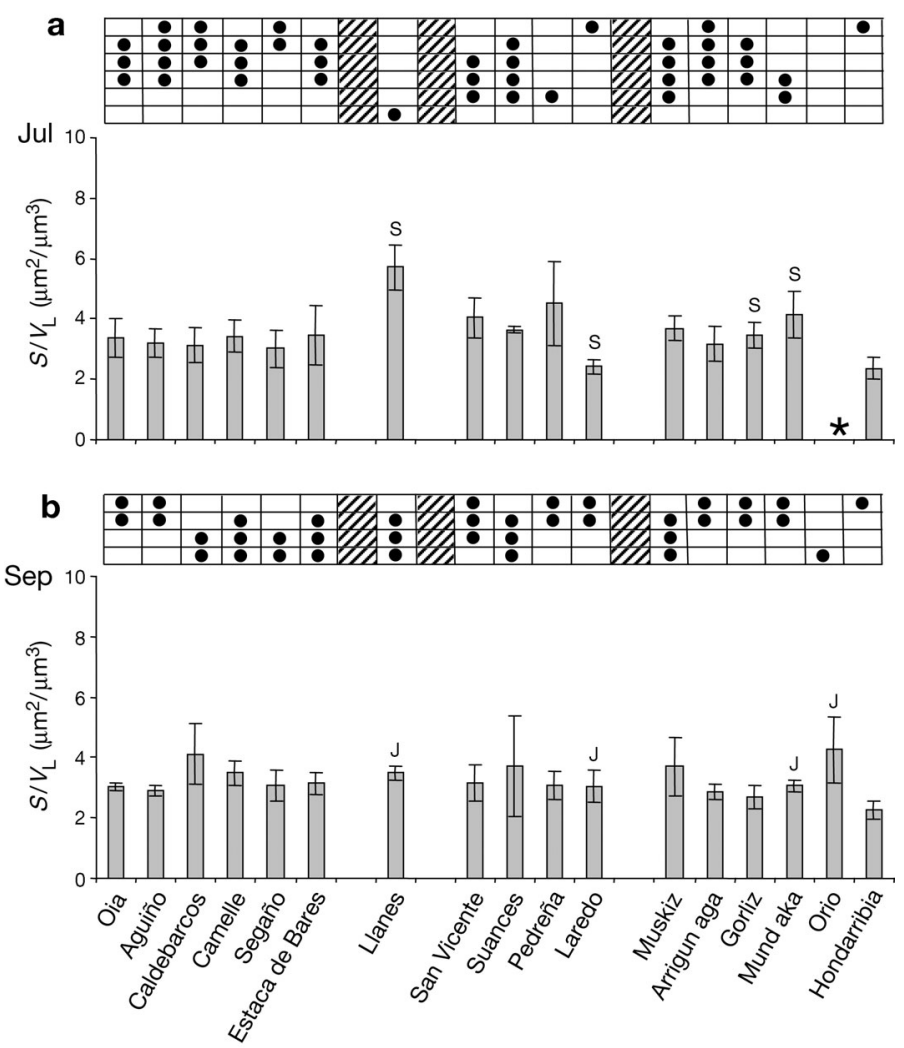

Fig. 5. Mytilus galloprovincialis. Lysosomal surface to volume ratio $\left(S / V_{\mathrm{L}}\right)$ in the digestive glands of mussels sampled along the coast of the northern Iberian Peninsula in (a) July and (b) September 2003. Error bars represent standard deviations. *: Lysosomes in mussels sampled in Orio in July were too small to be measured by image analysis. Letters over bars indicate months. Symbols and statistical significance as in Fig. 4 

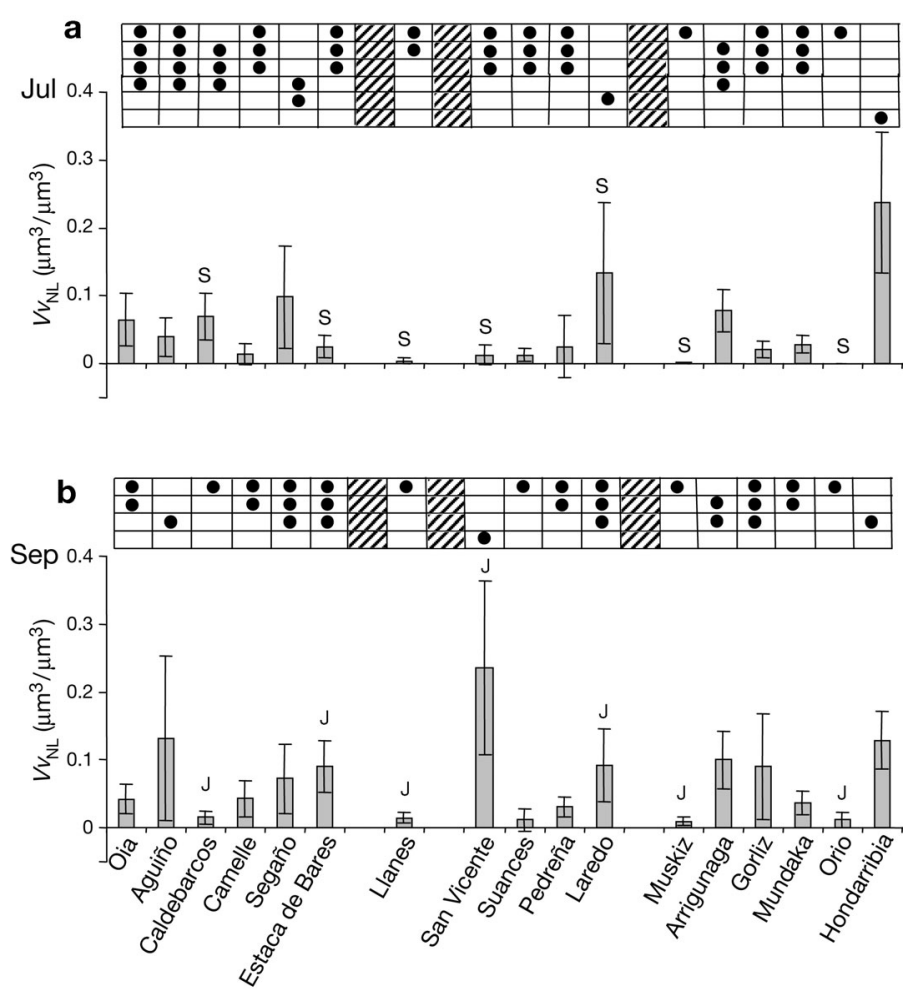

Fig. 6. Mytilus galloprovincialis. Volume density of intracellular neutral lipids $\left(V V_{\mathrm{NL}}\right)$ in the digestive glands of mussels sampled along the coast of the northern Iberian Peninsula in (a) July and (b) September 2003. Error bars represent standard deviations. Letters over bars indicate months. Symbols and statistical significance as in Fig. 4

lipids and peroxisome proliferation. FCI and gonad development stages were recorded as supporting parameters.

Except for 4 locations (Camelle, Suances, Laredo and Orio), higher values of FCI were found in July or September than in April. Accordingly, Soto et al. (1995) found a reduced FCI in mussels from the Abra estuary (Bay of Biscay) in early May. The body weight of mussels changes seasonally according to the relative rate of somatic or gonadal growth occurring during different periods of the life cycle (Hawkins \& Bayne 1985). Pre-spawning body weight increases, leading to highest peak values in summer and body weight decreases through winter (Talbot 1985). In general, in the 3 sampling periods, high FCI values were recorded in Hondarribia and low values in Oia, Llanes, Muskiz and Gorliz. Nevertheless, FCI values were within the normal range of variation (Soto et al. 1995), and this parameter did not appear to be significantly affected as a result of the 'Prestige' oil spill during the sampling period.

According to gonad development studies, mussels from different geographical locations showed only minor differences in gonad development. In April, the mature gonad stage was predominant at all locations, with only a few exceptions (Oia, Aguiño, Caldebarcos, Estaca de Bares and San Vicente). As expected, in July, mussels from all locations, except Llanes, were at a more advanced gonad stage than in April. Indeed, mussels from Camelle and Suances had begun the second gametogenesis cycle. Finally, in September, the gonads of most mussels were at a post-spawning stage and mussels from most locations were starting the second reproductive cycle. Exposure to the wateraccommodated fractions of crude and lubricant oils is known to produce alterations in the timing of the reproductive cycle in mussels (Cajaraville et al. 1992a). Because of the lack of previous data for mussels from the studied locations, further studies are needed to determine if the slight differences found among stations are due to the oil spill or to natural variability related to differences in temperature or other physicochemical variables.

Lysosomal alterations in molluscan digestive cells have been used as general biomarkers of pollution in laboratory and field studies (Moore 1988, Regoli 1992, Cajaraville et al. 1995, Marigómez et al. 1996, Marigómez \& Baybay-Villacorta 2003). In the present study, reduced membrane stability indicated disturbed health in mussels from all stations, but more marked in mussels from all Galician stations. Similarly, although the $V v_{\mathrm{L}}$ of lysosomes was low due to the reduction in lysosome numbers, lysosomal enlargement was observed at most stations, as shown by the low $S / V_{\mathrm{L}}$ values recorded (Marigómez et al. 1996, 2005, Marigómez \& Baybay-Villacorta 2003).

In field studies, lysosomal membrane stability has been shown to be a sensitive biomarker of general stress (Moore 1988, Regoli 1992). Generally, LP values $>20$ to 25 min indicate a healthy condition, whereas LP values <10 min reflect a severe stress situation (Viarengo et al. 2000). In the present study, LP values were low to extremely low all along the coast in both July and September. Previous field studies in the relatively clean locality of Plentzia (Bay of Biscay) revealed that LP values in August were $>20$ min (Izagirre \& Marigómez 2003), which in the present study was only observed in mussels collected from Orio in July. The lowest LP values were found in Galicia, which can be attributed to a stress situation or disturbed health, as previously described in mussels inhabiting heavily contaminated sites (Moore et al. 1987, Domouhtsidou \& Dimitriadis 2001, Marigómez et al. 2005). Particularly, petroleum hydrocarbons are known to affect the membrane stability of digestive gland lysosomes, and breaks in the lysosomal membrane have been related to the concentration of hydrocarbons in the digestive gland (Moore 1976, Moore et al. 1987). 

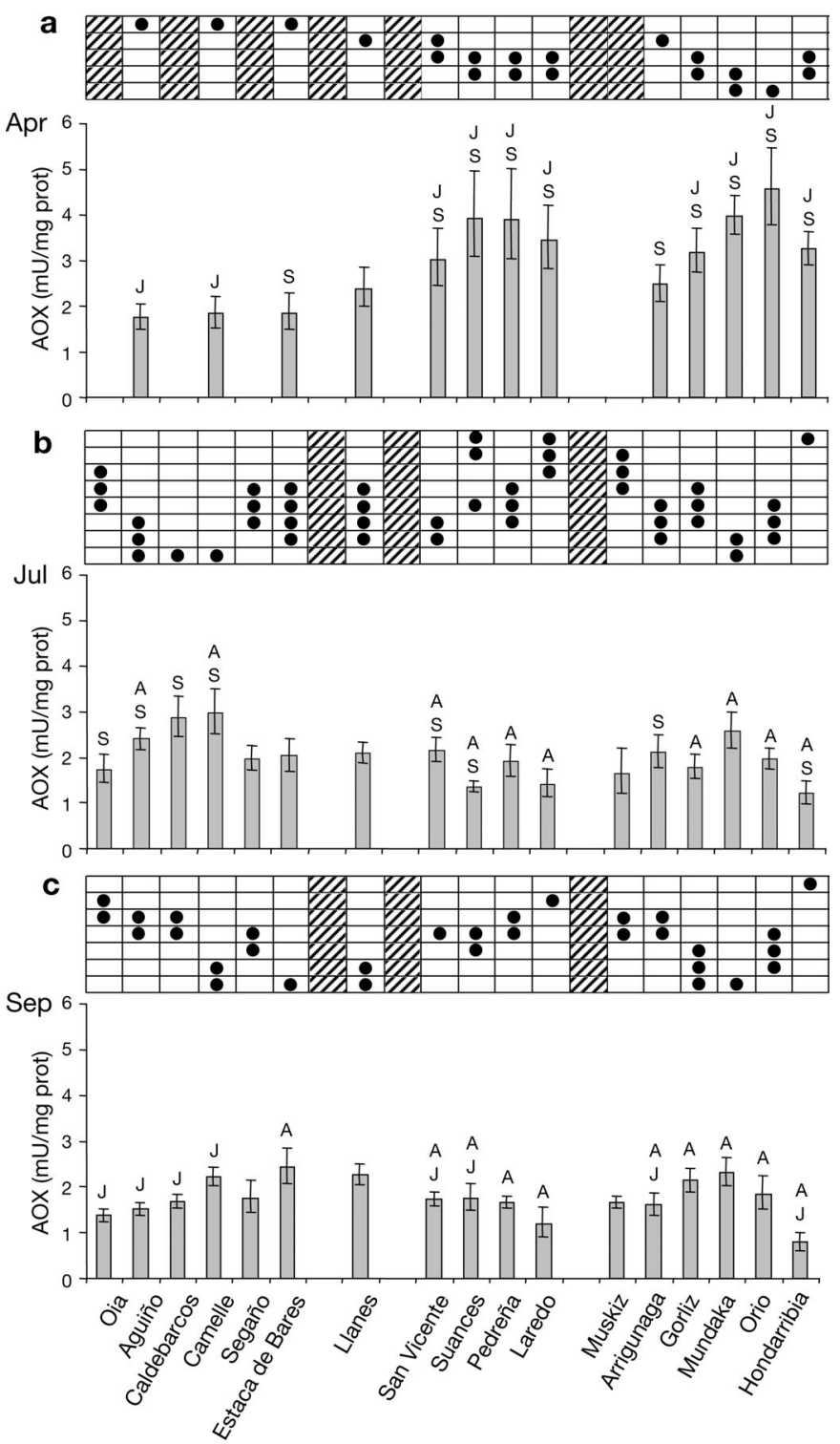

Fig. 7. Mytilus galloprovincialis. Acyl-CoA oxidase activity (AOX) in the digestive glands of mussels sampled along the coast of the northern Iberian Peninsula in (a) April, (b) July and (c) September 2003. Error bars representing standard deviations are asymmetric due to the logarithmic transformation of the data previous to statistical analysis. Letters over bars indicate months. For (a) April, data from Oia, Caldebarcos, Segaño and Muskiz are missing due to accidental loss of samples. Symbols and statistical significance as in Fig. 4

Organic pollutants can also produce alterations in the structure of digestive cell lysosomes in mussels (Moore et al. 1978, Cajaraville et al. 1995). Generally, it is accepted that hydrocarbons destabilise the lysosomal membrane to finally provoke structural changes such as lysosomal enlargement. Lysosomal enlargement in the digestive gland cells of mussels has been reported after experimental exposure to pollutants
(Cajaraville et al. 1995) and in field studies (Marigómez et al. 1996), although organic chemical pollutants might alternatively cause a reduction in lysosomal size and numbers (Marigómez et al. 1996, Marigómez \& Baybay-Villacorta 2003). In the present study, lysosomal enlargement occurred together with a severe reduction in lysosome numbers, as evidenced by reduced $V v_{\mathrm{L}}, S / V_{\mathrm{L}}$ and $N v_{\mathrm{L}}$ for both the Galician coast and the Bay of Biscay. For example, $S / V_{\mathrm{L}}$ values

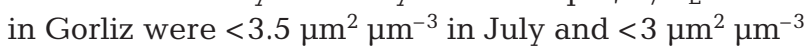

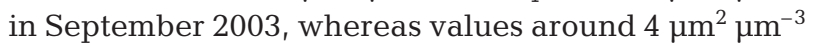
in August and $>5 \mu^{2} \mu^{-3}$ in March were recorded in a previous study at the same locality throughout 2001 (Izagirre \& Marigómez 2003). These observed alterations could be considered the consequence of either an effective detoxification mechanism (Cajaraville et al. 1995, Marigómez et al. 1996) or an advanced stage of pathological degeneration. This question can only be elucidated after more data series are collected for more extended periods during the next years and by assessing responses at more complex levels of biological organisation - an aspect which is currently under investigation (i.e. tissue level biomarkers; Cajaraville et al. 1992b).

Exposure to petroleum hydrocarbons provokes intracellular accumulation of neutral lipids in mussel digestive cells, which is evidenced by an increase in ORO staining (Moore 1988, Lowe \& Clarke 1989, Regoli 1992, Marigómez \& Baybay-Villacorta 2003). However, the variability in $V v_{\mathrm{NL}}$ was high, with heterogeneous ORO staining between individuals and between groups. This high variability could be related to the fact that neutral lipid accumulation has been reported to behave as an all-or-nothing response (Marigómez \& Baybay-Villacorta 2003). In addition, as shown in previous studies in Plentzia (Bay of Biscay), $V v_{\mathrm{NL}}$ values recorded in mussel digestive glands change seasonally according to the reproductive cycle, with almost inconspicuous levels between February and July and maximum peak values in September (Cancio et al. 1999). In the present study, several locations presented conspicuous ORO staining in July, with moderate-to-high levels at Galician locations and in Laredo, Arrigunaga and Hondarribia. Moreover, higher $V V_{\mathrm{NL}}$ values were recorded in September than in July. The present results might indicate exposure to organic pollutants, but further studies are required before feasible conclusions can be drawn.

Peroxisomes are single, membrane-bound organelles occurring in most eukaryotic cells. In sensitive organisms they are able to proliferate under exposure to a series of compounds, including PAHs, known as peroxisome proliferators (for a recent review see Cajaraville et al. 2003). Peroxisome proliferation is indicated by an increase in the peroxisomal volume density and 
the induction of some peroxisomal enzyme activities, such as AOX, although these 2 processes are not always parallel. In this survey, peroxisome proliferation was assessed in terms of induction of AOX activity.

Peroxisome proliferation has been proven to occur in mussels experimentally exposed to the water-accommodated fraction of crude and lubricant oils, as well as to model PAHs - benzo[a]pyrene-and other organic compounds such as polychlorinated biphenyls (PCBs) and phthalate-derived plasticisers (Cajaraville et al. 1997, Krishnakumar et al. 1997, Cancio et al. 1998). Field studies have also demonstrated the occurrence of this phenomenon in wild populations inhabiting contaminated areas (Porte et al. 2001, Cajaraville et al. 2003). As for the intracellular accumulation of neutral lipids, long-term studies along an annual cycle in the Abra and Plentzia estuaries (Bay of Biscay) have shown that peroxisomal parameters in mussels change seasonally with maximum values of both peroxisomal volume density and AOX activity in spring (Cancio et al. 1999, Orbea et al. 1999), which has to be taken into account when interpreting monitoring data.

In this work, the highest values of AOX activity were detected in mussels sampled in April, as expected, except at the Galician locations, which presented statistically lower values than mussels from the other locations. This lack of seasonal response in Galician mussels has previously been observed in mussels inhabiting areas chronically polluted by PAHs, such as Galea in the Abra estuary (Orbea et al. 1999). Thus, this lack of induction or inhibition of AOX activity in April in mussels from Galicia could be due to the presence of toxic compounds in concentrations that exert an acute toxic effect.

In the following samplings, AOX activity decreased gradually; the activities recorded in most of the Galician locations were comparable to those measured at the other sampling locations. However, in July, maximum values of AOX activity were obtained in mussels from Caldebarcos and Camelle, which were the most affected locations, situated just in front of where the tanker sunk. In September, AOX activity remained high in Camelle, indicating signs of peroxisome proliferation, probably due to the presence of organic pollutants in the environment.

Comparing the values obtained in Arrigunaga, Gorliz and Mundaka in 2003 with previous data covering the same seasons in 1996 and 2001 at the nearby sampling locations of Arriluze, Plentzia and Txatxarramendi, respectively (Cancio et al. 1999, A. Orbea et al. unpubl. results), AOX activity was very similar in April, probably indicating the maximum values of AOX activity reachable in mussels from these areas, but mussels displayed much higher AOX activity in July and September after the 'Prestige' oil spill.
In conclusion, the data obtained in this study are difficult to interpret due to the extension of the oil spill over time (at least $6 \mathrm{mo}$ ) and the area affected ( $>1000 \mathrm{~km}$ of coastline), as well as the absence of a valid control location along the coast of the northern Iberian Peninsula after the 'Prestige' oil spill. Furthermore, apart from some specific Basque localities, no previous data are available on biomarker responses in this area for comparative purposes. This makes it difficult to interpret the results obtained and highlights the need to establish a regular biomonitoring network along the Iberian coast, which should encompass assessment of the biological effects of pollution based on the use of biomarkers in conjunction with chemical analyses of contaminants (Cajaraville et al. 2000). In spite of these difficulties, some relevant conclusions can be drawn through comparison of the data obtained at the different sites and samplings. First, as shown by the ANOVAs, the effect of sampling location was significantly stronger than the effect of the sampling period on the studied biomarkers. Second, the employed biomarkers detected exposure to toxic chemicals and disturbed health in molluscs from the northwestern Iberian Peninsula coast after the 'Prestige' oil spill, especially in Galicia, as indicated by the reduced labilisation period of the lysosomal membrane and the loss of the ability to respond to seasonal variations in AOX activity. Most interestingly, the results obtained during the first year after the oil spill will provide the basis to assess the long-term effects of the spill on coastal ecosystems. In the framework of a multidisciplinary research project, the monitoring strategy applied in the present work will be continued for at least a 3 yr period (2004 to 2006), with the aim of establishing the long-term effects of the spill (see www.ehu.es/ImpactoBiologicoPrestige). In addition to the set of exposure and effect biomarkers applied in the present work, biomarkers for genotoxicity and reproduction effects will be included in future biomonitoring studies, since petroleum hydrocarbons are known genotoxic compounds (Venier et al. 2003) and recent data also indicate that PAHs exert endocrine disruption (Navas \& Segner 2000).

Acknowledgements. This work was supported by the Spanish Ministry of Science and Technology through 'Urgent ActionCoastal areas' and project PRESTEPSE (vem2003-20082CO6-01), by the Basque Government (ETORTEK actionsIMPRES) and by the University of the Basque Country through a grant to Consolidated Research Groups. The technical assistance of the personnel of the Cell Biology and Histology Lab (Faculty of Science and Technology, University of the Basque Country) in samplings and sample processing is gratefully acknowledged. Thanks also to Profs. F. Javier Cristobo and V. Urgorri (Univ Santiago de Compostela) for collaboration during sampling in Galicia. 


\section{LITERATURE CITED}

Au DWT (2004) The application of histo-cytopathological biomarkers in marine pollution monitoring: a review. Mar Pollut Bull 48:817-834

Bodkin JL, Ballachey BE, Dean TA, Fukuyama AK and 5 others (2002) Sea otter population status and the process of recovery from the 1989 'Exxon Valdez' oil spill. Mar Ecol Prog Ser 241:237-253

Cajaraville MP, Marigómez I, Angulo E (1991) Automated measurement of lysosomal structure alterations in oocytes of mussels exposed to petroleum hydrocarbons. Arch Environ Contam Toxicol 21:395-400

Cajaraville MP, Marigómez I, Angulo E (1992a) Comparative effects of the water accommodated fraction of three oils on mussels. 1. Survival, growth and gonad development. Comp Biochem Physiol 102C:103-112

Cajaraville MP, Marigómez I, Angulo E (1992b) Comparative effects of the water accommodated fraction of three oils on mussels. 2. Quantitative alterations in the structure of the digestive tubules. Comp Biochem Physiol 102C: 113-123

Cajaraville MP, Robledo Y, Etxeberria M, Marigómez I (1995) Cellular biomarkers as useful tools in the biological monitoring of environmental pollution: molluscan digestive lysosomes. In: Cajaraville MP (ed) Cell biology in environmental toxicology. University of the Basque Country Press Service, Bilbao, p 29-55

Cajaraville MP, Orbea A, Marigómez I, Cancio I (1997) Peroxisome proliferation in the digestive epithelium of mussels exposed to the water accommodated fraction of three oils. Comp Biochem Physiol 117C:233-242

Cajaraville MP, Bebianno MJ, Blasco J, Porte C, Sarasquete C, Viarengo A (2000) The use of biomarkers to assess the impact of pollution in coastal environments of the Iberian Peninsula: a practical approach. Sci Total Environ 247: 201-212

Cajaraville MP, Cancio I, Ibabe A, Orbea A (2003) Peroxisome proliferation as biomarker in environmental pollution assessment. In: Cajaraville MP (ed) Microscopy research and technique. Special issue on cell biology of peroxisomes, Vol 61. John Wiley \& Sons, New York, p 191-202

Cancio I, Orbea A, Völkl A, Fahimi HD, Cajaraville MP (1998) Induction of peroxisomal oxidases in mussels: comparison of effects of lubricant oil and benzo(a)pyrene with two typical peroxisome proliferators on peroxisome structure and function in Mytilus galloprovincialis. Toxicol Appl Pharmacol 149:64-72

Cancio I, Ibabe A, Cajaraville MP (1999) Seasonal variation of peroxisomal enzyme activities and peroxisomal structure in mussels Mytilus galloprovincialis and its relationship with the lipid content. Comp Biochem Physiol 123C: 135-144

Culling CFA (1974) Handbook of histopathological and histochemical techniques, 3rd edn. Butterworths, London

Domouhtsidou GP, Dimitriadis VK (2001) Lysosomal and lipid alterations in the digestive gland of mussels, Mytilus galloprovincialis (L.) as biomarkers of environmental stress. Environ Pollut 115:123-137

Esler D, Bowman TD, Trust KA, Ballacey BE, Dean TA, Jewett SC, O'Clair CE (2002) Harlequin duck population recovery following the 'Exxon Valdez' oil spill: progress, process and constraints. Mar Ecol Prog Ser 241:271-286

Fernley PW, Moore MN, Lowe DM, Donkin P, Evans S (2000) Impact of the Sea Empress oil spill on lysosomal stability in mussel blood cells. Mar Environ Res 50:451-455
Golet GM, Seiser PE, McGuire AD, Roby DD and 6 others (2002) Long-term direct and indirect effects of the 'Exxon Valdez' oil spill on pigeon guillemots in Prince William Sound, Alaska. Mar Ecol Prog Ser 241:287-304

Harvey JS, Lyons BP, Page TS, Stewart C, Parry JM (1999) An assessment of the genotoxic impact of the Sea Empress oil spill by the measurement of DNA adduct levels in selected invertebrate and vertebrate species. Mutat Res 441: 103-114

Hawkins AJS, Bayne BL (1985) Seasonal variation in the relative utilisation of carbon and nitrogen by the mussel Mytilus edulis: budgets, conversion efficiencies and maintenance requirements. Mar Ecol Prog Ser 25:181-188

Izagirre U, Marigómez I (2003) Tide and season effects on lysosomal biomarkers in mussel digestive cells. In: Abstracts, 5th Iberian and 2nd Iberoamerican Congress of Environmental Contamination and Toxicology, Porto, p 194

Jewett SC, Dean TA, Woodin BR, Hoberg MK, Stegeman JJ (2002) Exposure to hydrocarbons 10 years after the Exxon Valdez oil spill: evidence from cytochrome P4501A expression and biliary FACs in nearshore demersal fish. Mar Environ Res 54:21-48

Kirby MF, Neall P, Tylor T (1999) EROD activity measured in flatfish from the area of the Sea Empress oil spill. Chemosphere 38:2929-2949

Krishnakumar PK, Casillas E, Varanasi V (1997) Cytochemical responses in the digestive tissue of Mytilus edulis complex exposed to microencapsulated PAHs or PCBs. Comp Biochem Physiol 118C:11-18

Lobel PB, Wright DA (1982) Relationship between body zinc concentration and allometric growth measurements in the mussel Mytilus edulis. Mar Biol 66:145-150

Lowe DM, Clarke KR (1989) Contaminant-induced changes in the structure of the digestive epithelium of Mytilus edulis. Aquat Toxicol 15:345-358

Lowe DM, Moore MN, Clarke KR (1981) Effects of oil on digestive cells in mussels: quantitative alterations in cellular and lysosomal structure. Aquat Toxicol 1:213-226

Lowry OH, Rosebrough NJ, Farr AL, Randall RJ (1951) Protein measurement with the Folin phenol reagent. J Biol Chem 193:265-275

Lyons BP, Harvey JS, Parry JM (1997) An initial assessment of the genotoxic impact of the Sea Empress oil spill by measurement of DNA adduct levels in intertidal teleost Lipophrys pholis. Mutat Res 390:263-268

Marigómez I, Baybay-Villacorta L (2003) Pollutant-specific and general lysosomal responses in digestive cells of mussels exposed to model organic chemicals. Aquat Toxicol 64:235-257

Marigómez I, Orbea A, Olabarrieta I, Etxeberria M, Cajaraville MP (1996) Structural changes in the digestive lysosomal system of sentinel mussels as biomarkers of environmental stress in Mussel-Watch programmes. Comp Biochem Physiol 113C:291-297

Marigómez I, Soto M, Orbea A, Cancio I, Cajaraville MP (2004) Biomonitoring of environmental pollution in the Basque coast using molecular, cellular and tissue-level biomarkers: an integrative approach, Chap 14. In: Borja A, Collins $M$ (eds) Oceanography and marine environment in the Basque Country. Elsevier Oceanography Ser 70. Elsevier, Amsterdam, p 335-364

Marigómez I, Lekube X, Cajaraville MP, Domouhtsidou G, Dimitriadis V (2005) Comparison of cytochemical procedures to estimate lysosomal biomarkers in mussel digestive cells. Aquat Toxicol 75:86-95

McCarthy JF, Shugart LR (1990) Biological markers of envi- 
ronmental contamination. In: McCarthy JF, Shugart LR (eds) Biomarkers of environmental contamination. Lewis Publishers, Boca Raton, FL, p 3-14

Moore MN (1976) Cytochemical demonstration of latency of lysosomal hydrolases in digestive cells of the common mussel (Mytilus edulis), and changes induced by thermal stress. Cell Tissue Res 175:279-287

Moore MN (1988) Cytochemical responses of the lysosomal system and NADPH-ferrihemoprotein reductase in molluscan digestive cells to environmental and experimental exposure to xenobiotics. Mar Ecol Prog Ser 46:81-89

Moore MN, Lowe DM, Feith PEM (1978) Lysosomal responses to experimentally injected anthracene in the digestive cells of Mytilus edulis. Mar Biol 48:297-302

Moore MN, Pipe RK, Farrar SV (1987) Induction of lysosomal lipid accumulation and fatty degeneration by polycyclic aromatic hydrocarbons in molluscan digestive cells. Mar Environ Res 4:352-353

Navas JM, Segner H (2000) Antiestrogenicity of $\beta$-naphthoflavone and PAHs in cultured rainbow trout hepatocytes: evidence for a role of the arylhydrocarbon receptor. Aquat Toxicol 51:79-92

Orbea A, Marigómez I, Fernández C, Tarazona JV, Cancio I, Cajaraville MP (1999) Structure of peroxisomes and activity of the marker enzyme catalase in digestive epithelial cells in relation to PAH content of mussels from two Basque estuaries (Bay of Biscay): seasonal and sitespecific variations. Arch Environ Contam Toxicol 36: 158-166

Peters LD, Shaw JP, Nott M, O'Hara SCM, Livingstone DR (1999) Development of cytochrome P450 as a biomarker of organic pollution in Mytilus sp.: field studies in United Kingdom ('Sea Empress' oil spill) and the Mediterranean Sea. Biomarkers 4:425-441

Peterson CH, Rice SD, Short JW, Esler D, Bodkin JL, Ballachey BE, Irons DB (2003) Long-term ecosystem response to the Exxon Valdez oil spill. Science 302:2082-2086

Porte C, Biosca X, Solé M, Albaigés J (2000) The Aegean Sea oil spill on the Galician coast (NW Spain). III. The assessment of long-term sublethal effects on mussels. Biomarkers 5:436-444

Porte C, Solé M, Borghi V, Martínez M and 6 others (2001) Chemical, biochemical and cellular responses in digestive gland of the mussel Mytilus galloprovincialis from the Spanish Mediterranean coast. Biomarkers 6:335-350

Editorial responsibility: Charles Peterson (Contributing Editor), Morehead City, North Carolina, USA
Regoli F (1992) Lysosomal responses as a sensitive stress index in biomonitoring heavy metal pollution. Mar Ecol Prog Ser 84:63-69

Seed R (1969) The ecology of Mytilus edulis L. (Lamellibranchiata) on exposed rocky shores. Oecologia 3: $277-316$

Small GM, Burdett K, Connock MJ (1985) A sensitive spectrophotometric assay for peroxisomal acyl-CoA oxidase. Biochem J 227:205-210

Sokal RR, Rohlf FJ (1995) Biometry. The principles and practice of statistics in biological research, 3rd edn. WH Freeman, New York

Solé M, Porte C, Biosca X, Mitchelmore CL, Chipman JK, Livingstone DR, Albaigés J (1996) Effects of the 'Aegean Sea' oil spill on biotransformation enzymes, oxidative stress and DNA-adducts in digestive gland of the mussel (Mytilus edulis L.). Comp Biochem Physiol 113C: $257-265$

Soto M, Kortabitarte M, Marigómez I (1995) Bioavailable heavy metals in estuarine waters as assessed by metal/ shell-weight indices in sentinel mussels Mytilus galloprovincialis. Mar Ecol Prog Ser 125:127-136

Stagg RM (1998) The development of an international programme for monitoring the biological effects of contamination in the OSPAR convention area. Mar Environ Res 46: $307-313$

Talbot V (1985) Heavy metal concentration in the oyster Saccostrea cucullata and Saccostrea sp. (probably S. commercialis) from the Dampier archipelago, Western Australia. Aust J Mar Freshw Res 36:169-175

Trust KA, Esler D, Woodin BR, Stegeman JJ (2000) Cytochrome P450 1A induction in sea ducks inhabiting nearshore areas of Prince William Sound, Alaska. Mar Pollut Bull 40:397-403

UNEP/RAMOGE (1999) Manual on the biomarkers recommended for the MED POL biomonitoring programme. UNEP, Athens

Venier P, Tallandini L, Bisol PM (2003) Characterization of coastal sites by applying genetic and genotoxicity markers in Mytilus galloprovincialis and Tapes philippinarum. Chem Ecol 19:113-128

Viarengo A, Lafaurie M, Gabrielides GP, Fabbri R, Marro A, Romeo M (2000) Critical evaluation of an intercalibration exercise undertaken in the framework of the MED POL biomonitoring program. Mar Environ Res 49:1-18

Submitted: February 22, 2005; Accepted: October 6, 2005 Proofs received from author(s): November 30, 2005 